\title{
RESEARCH
}

Open Access

\section{Genotype-phenotype correlations in children and adolescents with nonclassical congenital adrenal hyperplasia due to 21- hydroxylase deficiency}

Helmuth-Günther Dörr ${ }^{1 *}$ (D, Nadja Schulze', Markus Bettendorf ${ }^{2}$, Gerhard Binder $^{3}$, Walter Bonfig ${ }^{4}$, Christian Denzer ${ }^{5}$, Desiree Dunstheimer ${ }^{6}$, Kirsten Salzgeber ${ }^{7}$, Heinrich Schmidt ${ }^{8}$, Karl Otfried Schwab ${ }^{9}$, Egbert Voss ${ }^{10}$,

Martin Wabitsch ${ }^{5}$ and Joachim Wölfle

\begin{abstract}
Background: Nonclassical congenital adrenal hyperplasia due to 21-hydroxylase deficiency is caused by mutations in the active 21-hydroxylase gene (CYP21A2). The clinical symptoms can vary greatly. To date, no systematic studies have been undertaken in Germany.
\end{abstract}

Aims: Description of the phenotype, evaluation of the diagnostics and genotype-phenotype correlation

Patients and methodology: Retrospective analysis of the data of 134 patients (age range 0.1-18.6 years) in a multicentre study covering 10 paediatric endocrinology centres in Bavaria and Baden-Württemberg. The data was gathered on site from the medical records. Two hundred and thirty-three alleles with a mutation of the CYP21A2 gene were identified in 126 patients. A genotype-phenotype correlation of the mutation findings was undertaken ( $\mathrm{C} 1$, severe/mild; $\mathrm{C} 2$, mild/mild). Individuals with a heterozygous mutation of the CYP21A2 were also included (C3). The data was collected with the approval of the ethics committee of the University Hospital of Erlangen during the period of 2014 and 2015.

Results (MW \pm SD): One hundred and seventeen out of 134 patients $(115 \mathrm{f}, 29 \mathrm{~m})$ were symptomatic. The chronological age (CA) at diagnosis was $7.1 \pm 4.4$ years. The most frequent symptom (73.5\%) was premature pubarche. The height-SDS on diagnosis was $0.8 \pm 1.3$ and the BMI-SDS was $0.8 \pm 1.2$. Bone age (BA) was ascertained in $82.9 \%$ of the symptomatic patients. The difference between BA and CA was $1.9 \pm 1.4$ years. Basal 17OHP concentrations were $14.5 \pm 19.1 \mathrm{ng} / \mathrm{ml}$ (18 patients $<2$ $\mathrm{ng} / \mathrm{ml}$ ). In total, $58.1 \%$ mild and 34.7\% severe mutations were found. The most common mutation was p.Val281Leu (39.1\%); $65.8 \%$ of the patients could be allocated to group C1. No phenotypical differences were found between the 3 mutation groups. The 17OHP levels (basal and after ACTH) in the standard ACTH stimulation test were highest in group $\mathrm{C} 1$ and also significantly higher in group C2 as in C3, the ACTH-stimulated cortisol levels $(\mathrm{ng} / \mathrm{ml})$ were significantly lower in groups C1 (192.1 \pm 62.5$)$ and C2 (218 \pm 50$)$ than in C3 (297.3 \pm 98.7$)$.

(Continued on next page)

\footnotetext{
* Correspondence: helmuth-guenther.doerr@uk-erlangen.de

This article is published simultaneously in Molecular and Cellular Pediatrics

and in the German language in Monatsschrift Kinderheilkunde (DOI: 10.1007/ s00112-020-00976-y).

${ }^{1}$ Paediatric Endocrinology, University Children's Hospital, Erlangen, Germany

Full list of author information is available at the end of the article
}

\section{Springer Open}

(c) The Author(s). 2020 Open Access This article is licensed under a Creative Commons Attribution 4.0 International License, which permits use, sharing, adaptation, distribution and reproduction in any medium or format, as long as you give appropriate credit to the original author(s) and the source, provide a link to the Creative Commons licence, and indicate if changes were made. The images or other third party material in this article are included in the article's Creative Commons licence, unless indicated otherwise in a credit line to the material. If material is not included in the article's Creative Commons licence and your intended use is not permitted by statutory regulation or exceeds the permitted use, you will need to obtain permission directly from the copyright holder. To view a copy of this licence, visit http://creativecommons.org/licenses/by/4.0/. 


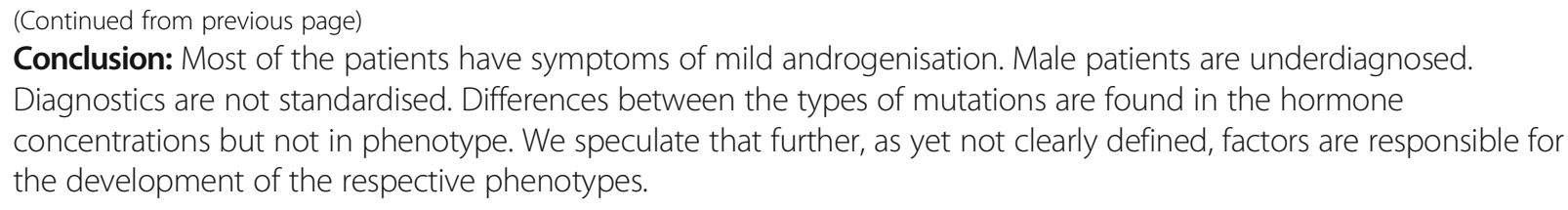

Keywords: CYP21A2 mutations, 21-Hydroxylase deficiency, Androgenisation, Premature pubarche, 17OHP, ACTH stimulation test

\section{Background}

Nonclassical congenital adrenal hyperplasia due to 21hydroxylase deficiency (NC-CAH) is caused by mutations in the active 21-hydroxylase gene (CYP21A2) and is the most common congenital disorder of steroid biosynthesis of the adrenal gland, with an estimated prevalence of 1:200-1:1000 in the Caucasian population [1,2]. The mutations which result in classic congenital adrenal hyperplasia $(\mathrm{CAH})$ or $\mathrm{NC}-\mathrm{CAH}$ are classified internationally according to the residual activity of 21hydroxylase in the mutation groups $0, \mathrm{~A}, \mathrm{~B}$ and $\mathrm{C}[3-5]$. Severe mutations are found in groups $0, \mathrm{~A}$ and $\mathrm{B}$ while the patients with NC-CAH belong to mutation group $\mathrm{C}$. Most patients are compound heterozygous, i.e. the genotype comprises a combination of mutations, which result in a mild reduction in enzyme activity on one allele and of mutations causing either a total ( $0 \%$ residual activity), a serious (about $2-5 \%$ residual activity) or a mild (20$60 \%$ residual activity) reduction in enzyme activity on the other alleles $[4,6]$. The phenotype is influenced by the activity of the less affected allele, and the residual activity of 21-hydroxylase in the patients is around 20$50 \%$ [7]. However, the phenotypical degree of severity within a genotype can vary greatly and different phenotypes can be associated with the same mutation [8].

To date, there are no systematic studies for children with $\mathrm{NC}-\mathrm{CAH}$ in Germany, and numbers on prevalence are also lacking. At the bi-annual meeting of paediatric endocrinologists in Bavaria and Baden-Württemberg, it was decided to analyse data of affected children in order to answer questions regarding clinical presentation, laboratory and molecular genetic diagnostics and the correlation of genotype to phenotype.

\section{Patients and methods}

The study included 134 children and adolescents (age range 0.1-18.6 years) born between 1972 and 2014 who are treated in 10 different paediatric endocrinology centres in Bavaria and Baden-Württemberg. The study was planned during the bi-annual meeting of paediatric endocrinologists in Ulm. The data was collected retrospectively in the participating hospitals by one person (N.Sch.) in 2014 and 2015, or the data was entered into an Excel table in those centres with few patients.

The height and the body mass index (BMI) of the patients were calculated in standard deviation scores (SDS) in accordance with the reference values of Kromeyer-Hauschild et al. [9]. An SDS value specifies the difference of a measured value to the mean value of the reference population of the same age and is calculated from the difference of the measured value (actual value) and the mean value (nominal value) divided by the corresponding standard deviation of the mean value. Bone age (X-ray of the left hand) was evaluated according to the Greulich and Pyle Atlas method [10]. Pubarche before the 8th birthday in girls and before the 9th birthday in boys was assessed as premature pubarche.

The serum concentrations of 17-hydroxyprogesterone (17-OHP) and cortisol were measured in the individual centres according to the directive of the German Medical Association for the Quality Assurance of Laboratory Medical Examinations (Rili-BÄK). The blood samples were taken in the morning and in the early follicular phase in girls who were menstruating. A standard ACTH stimulation test was carried out on 83 patients (i.v. $250 \mu \mathrm{g}$, blood samples taken at 0 and $60 \mathrm{~min}$ ) and 17-OHP and cortisol were measured. The following are conversion factors for conventional units to SI units: $17 \mathrm{OHP}, \mathrm{ng} / \mathrm{ml} \times 3=\mathrm{nmol} / \mathrm{l} ;$ cortisol, $\mathrm{ng} / \mathrm{ml} \times 2.76=$ $\mathrm{nmol} / \mathrm{l}$.

The molecular genetic diagnostics with complete sequencing of the CYP21A2 gene, and additionally with different methods (MLPA, semi-quantitative PCR) an analysis of the number of copies of the CYP21A2 gene in comparison with the pseudogene CYP21A1P, was performed in different molecular genetic laboratories. Results of the molecular genetic analysis of 126 patients were available. The patients were divided into three groups according to the number of allele combinations of the CYP21A2 gene which were found. Group $\mathrm{C} 1$ is compound heterozygous patients with a severe mutation on one allele (mutations from groups $0, \mathrm{~A}$ or $\mathrm{B}$ ) and a mild mutation on the other allele (mutation from group $\mathrm{C}$ ), group $\mathrm{C} 2$ is patients with a mild mutation (heterozygous or homozygous) 
on both alleles (mutation from group $\mathrm{C}$ ) and group C3 is heterozygous individuals with only a mild heterozygous mutation on one allele.

\section{Statistics}

All statistical analyses were performed using SPSS 23.0 software (IBM Inc., USA), Quantitative data are presented as the mean \pm SD. Normality of the sample was examined by the Shapiro-Wilk test. Changes in clinical and laboratory variables between the different mutation groups were analysed using one-way ANOVA, followed by the post hoc comparisons using Tukey's test. Statistical significance was considered with a 2 -sided $P$ value of $<0.05$.

\section{Results}

\section{Clinical findings}

The diagnosis was made in 134 patients (105 f, $29 \mathrm{~m})$ at a mean age of $7.1 \pm 4.4(\mathrm{SD})$ years. Most of the children were diagnosed between the ages of 6 and 10 years (Table 1). $78.4 \%$ of patients were female; the ratio of female to male was 3.6:1. One hundred and seventeen patients $(97 \mathrm{f}, 20 \mathrm{~m})$ presented to outpatients' clinics with a variety of clinical symptoms, while $17(8 \mathrm{f}, 7 \mathrm{~m})$ did not yet have any symptoms at the time the data was collected. In these cases, the diagnosis was made in the process of prenatal diagnostics $(n=4)$, in CAH newborn screening $(n=6)$ and during examination of family members with affected siblings $(n=7)$.

Premature pubarche was the most frequent symptom found in the symptomatic patients with $73.5 \%$, followed by acne $22.2 \%$, clitoris hypertrophy $19.5 \%$, hirsutism $14.4 \%$ and seborrhoea $10.3 \%$. It must be borne in mind that some symptoms did not present in isolation but also in different combinations with other symptoms. The average time from the start of symptoms to diagnosis was more than 1 year. At the time of diagnosis, the mean height-SDS was $0.8 \pm 1.3$ (SD) and the BMI-SDS was 0.8 $\pm 1.2(\mathrm{SD})$. Bone age was determined in 97/117 patients and was, on average, $9.3 \pm 3.7(\mathrm{SD})$ years. The difference between bone age and chronological age was on average $1.9 \pm 1.4(\mathrm{SD})$ years. Bone age was accelerated in $70 \mathrm{pa}-$ tients $(72.2 \%)>1$ year.

Table 1 Age distribution of the patients at diagnosis

\begin{tabular}{lll}
\hline Group & Number & $\%$ \\
\hline $0-1$ year & 16 & 11.9 \\
$1-6$ years & 27 & 20.1 \\
6-10 years & 66 & 49.3 \\
$>10$ years & 25 & 18.7 \\
Total & 134 & 100.0 \\
\hline
\end{tabular}

\section{Laboratory diagnostics}

On the first visit, the mean basal 17OHP concentrations $(n=130)$ were $14.5 \pm 19.1$ (SD) $\mathrm{ng} / \mathrm{ml}$ (range, 0.3-112). No significant differences between the different age groups were seen either for the basal or for the stimulated 17-OHP (Fig. 1). The basal 17OHP levels were $<2$ $\mathrm{ng} / \mathrm{ml}$ in 18 patients and $>2 \mathrm{ng} / \mathrm{ml}$ in 112 patients. In the ACTH test $(n=83)$, the $17 \mathrm{OHP}$ concentrations increased from an average of $18.8 \pm 24.3(\mathrm{SD})$ to $61.1 \pm$ 79.9 (SD) $\mathrm{ng} / \mathrm{ml}$ after $60 \mathrm{~min}$. In 13 patients with a basal $17 \mathrm{OHP}<2 \mathrm{ng} / \mathrm{ml}$, the ACTH-stimulated 17OHP levels were $>10 \mathrm{ng} / \mathrm{ml}$ in 5 patients, whereas the levels did not increase in 8 patients.

Cortisol levels $(\mathrm{ng} / \mathrm{ml})$ were measured in the ACTH test in 74 patients and could be stimulated from mean $127.2 \pm 57.2(\mathrm{SD})$ to $225.9 \pm 79.1$ (SD). After ACTH stimulation, 20 patients had maximal cortisol levels of $<$ $180 \mathrm{ng} / \mathrm{ml}(<500 \mathrm{nmol} / \mathrm{L})$.

\section{Molecular analysis}

We identified 233 alleles with a mutation in the CYP21A2 gene in 126 patients. Of these, about $58 \%$ belong to the group with mild mutations and $34.7 \%$ to the severe mutations. The point mutation p.Val281Leu was found most frequently in the mild mutations (39.1\%), followed by p.Pro453Ser (8.2\%) and p.Pro30Leu (6.9\%) mutations. A deletion of the CYP21A2 gene was most frequent among the severe mutations (11.1\%), followed by the p.Ile172Asn mutation (6.9\%), small gene conversions $(6.0 \%)$ and the c. $290-13 \mathrm{~A} / \mathrm{C}>\mathrm{G}$ mutation (5.2\%). There was a deletion of the pseudogene CYP21A1P on five alleles $(2.1 \%)$. The mutation p.Gln318X in combination with a heterozygous duplication of the CYP21A2 gene was found on two alleles ( $0.9 \%)$.

Most of the patients (65.8\%) were compound heterozygous with both a severe and a mild mutation, and they were assigned to group $\mathrm{C} 1$. In group $\mathrm{C} 2$, there were 21

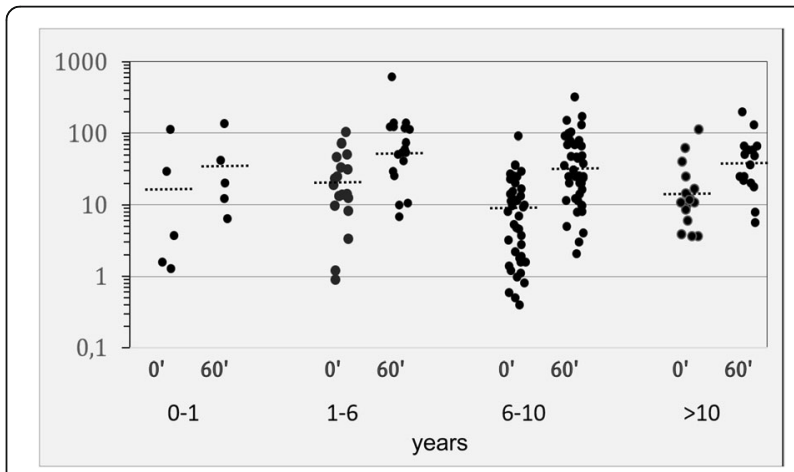

Fig. 1 Serum concentrations of $17 \mathrm{OHP}$ (ng/ml; logarithmic scale) in the ACTH test $(0,60 \mathrm{~min})$ in relation to the different age groups (years); 0-1 $(n=5), 1-6(n=18)$, and 6-10 $(n=43),>10(n=17)$; black dotted line, median; conversion factor to $\mathrm{Sl}, \mathrm{ng} / \mathrm{ml} \times 3$ $=\mathrm{nmol} / \mathrm{I}$ 
patients, each with mild mutations (heterozygous: $n=$ 11, homozygous: $n=10$ ) on both alleles (16.6\%). Only one mutation was found in 17 individuals (13.4\%) (group C3). Patients with deletions of the pseudogene and with a duplication of the CYP21A2 gene were not included.

\section{Genotype-phenotype correlation}

As shown in Table 2, group C1 comprised 83 patients (63 f, $20 \mathrm{~m}$ ) with both a severe and a mild mutation of the CYPA2-gene. Of these, 71 patients (85.5\%) were symptomatic. Group C2 comprised 21 patients (19 f, 2 $\mathrm{m})$ with two mild mutations. In this group, all patients except one boy were symptomatic (95.2\%). Group C3 encompassed the individuals (13 f, $4 \mathrm{~m}$ ) with a heterozygous CYP21A2 gene mutation. Here, too, 94.1\% (16/17) were symptomatic.

Premature pubarche was the most frequent symptom in all three mutation groups. No significant phenotypical differences were found between the three mutation groups; however, marked differences were seen in the hormone levels. The basal 17-OHP concentrations in group $\mathrm{C} 1$ were significantly higher than in C2 $(p<0.001)$ and C3 $(p<0.001)$. The difference between $\mathrm{C} 2$ and $\mathrm{C} 3$ was also significant $(p$ $<0.05)$. After ACTH the stimulated 17-OHP in groups $\mathrm{C} 1$ and $\mathrm{C} 2$ were significantly greater than in C3 $(p<0.01)$; no such differences were found between C2 and C3 (Fig. 2). No difference was seen in basal cortisol levels between the 3 groups. After ACTH stimulation, the maximal cortisol level in the groups $\mathrm{C} 1$ and $\mathrm{C} 2$ was significantly lower than in $\mathrm{C} 3$ $(p<0.01)$, while no differences were found between groups $\mathrm{C} 1$ and $\mathrm{C} 2$. Insufficient cortisol reserves (max. cortisol $<180 \mathrm{ng} / \mathrm{ml}$ ) were seen in 20 patients $(\mathrm{C} 1: n$ $=18 ; \mathrm{C} 2: n=2)$.

\section{Discussion}

Classic CAH occurs in two clinical forms, a form with salt wasting and a simple virilising form without aldosterone deficiency [11-13], whereas, as a rule, only symptoms of increased androgen production are seen in NC$\mathrm{CAH}[14,15]$. The clinical symptoms vary greatly. When the symptoms are less pronounced, many patients, and particularly the boys, will be diagnosed only by chance or not at all $[2,16]$. In almost all published studies, the

Table 2 Demographic and clinical characteristics of the mutation groups C1, C2 and C3; mean \pm standard deviation (SD); conversion factors: $170 \mathrm{HP} \mathrm{ng} / \mathrm{ml} \times 3=\mathrm{nmol} / \mathrm{L}$, cortisol $\mathrm{ng} / \mathrm{ml} \times 27.6=\mathrm{nmol} / \mathrm{L}$

\begin{tabular}{|c|c|c|c|c|}
\hline Groups & $\mathrm{C} 1$ & $\mathrm{C} 2$ & $\mathrm{C} 3$ & $p$ \\
\hline Mutations & severe/mild & mild/mild & heterozygous & \\
\hline Number of patients/individuals ( $n$ ) & 83 & 21 & 17 & \\
\hline Sex $(f / m)$ & $63 / 20$ & $19 / 2$ & $13 / 4$ & \\
\hline Chronological age (CA) at diagnosis (years) & $6.9 \pm 4.3$ & $6.2 \pm 3.3$ & $9.0 \pm 5.1$ & ns \\
\hline Symptomatic [n (\%)] & $71(85.5)$ & $20(95.2)$ & $16(94.1)$ & ns \\
\hline \multicolumn{5}{|l|}{ Symptoms (\%) } \\
\hline Premature pubarche & 73.2 & 85.0 & 68.8 & ns \\
\hline Acne & 23.9 & 30.0 & 18.8 & ns \\
\hline Clitoris hypertrophy* & 17.2 & 15.7 & 12.5 & ns \\
\hline Hirsutism* & 9.5 & 5.2 & 3.1 & $<0.01 \mathrm{a}$ \\
\hline Seborrhoea & 9.9 & 5.0 & 18.8 & $<0.05^{c}$ \\
\hline Height (SDS) & $0.8 \pm 1.3$ & $1.1 \pm 1.3$ & $0.2 \pm 1.3$ & ns \\
\hline Bone Age $(\mathrm{BA})>1$ year $(\%)$ & 73.3 & 84.2 & 80.0 & ns \\
\hline Delta BA-CA (years) & $2.0 \pm 1.5$ & $1.9 \pm 1.4$ & $1.8 \pm 1.0$ & ns \\
\hline \multirow[t]{2}{*}{$17 \mathrm{OHP}(\mathrm{ng} / \mathrm{ml})$} & $19.5 \pm 22.4$ & $9.4 \pm 7.4$ & $4.1 \pm 6.6$ & $<0.01 a^{\prime} b$ \\
\hline & & & & $<0.05 c$ \\
\hline ACTH test $(n)$ & 46 & 14 & 13 & \\
\hline $17 \mathrm{OHP}(\mathrm{ng} / \mathrm{ml}) 0 \mathrm{~min}$ & $27.3 \pm 28.8$ & $12.7 \pm 11.1$ & $2.7 \pm 2.6$ & $<0.01 a^{\prime} b^{\prime} c$ \\
\hline 17OHP after ACTH & $83.7 \pm 97.4$ & $58.7 \pm 37.3$ & $9.0 \pm 4.2$ & $<0.001 a^{\prime} c$ \\
\hline Cortisol (ng/ml) 0 min & $119.4 \pm 53.0$ & $134.9 \pm 56.8$ & $112.8 \pm 69.8$ & ns \\
\hline Cortisol after ACTH & $192.0 \pm 62.5$ & $218.4 \pm 50.1$ & $297.3 \pm 98.7$ & $<0.01^{\mathrm{a}, \mathrm{c}}$ \\
\hline
\end{tabular}

ns not significant

*In relation to the number of girls

${ }^{a}$ Significant differences between groups $\mathrm{C} 1$ and $\mathrm{C} 3$

${ }^{b}$ Significant differences between groups $\mathrm{C} 1$ and $\mathrm{C} 2$

'Significant differences between groups C2 and C3 


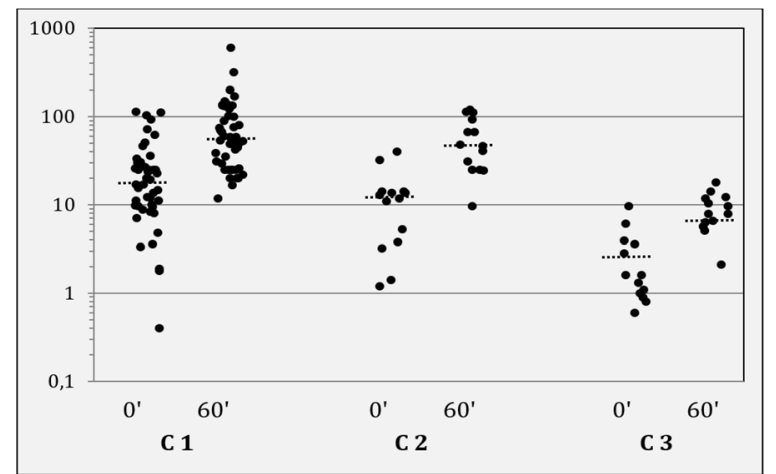

Fig. 2 Serum concentrations of 17OHP ( $\mathrm{ng} / \mathrm{ml}$; logarithmic scale) in the $\mathrm{ACTH}$ test $(0,60 \mathrm{~min})$ in relation to the mutation groups: $\mathrm{Cl}$ (severe/mild; $n=46$ ), C2 (mild/mild; $n=14$ ), and C3 (heterozygous; $n=13$ ); black dotted line, median; conversion factor to $\mathrm{Sl}, \mathrm{ng} / \mathrm{ml} \times 3$ $=\mathrm{nmol} / \mathrm{l}$

number of male patients was markedly smaller than the number of female patients [6,17-19]. In our cohort, the mean age of the patients at diagnosis was 7.1 years and 8.3 years in a comparable study in Turkey [19]. In most of the studies, the mean age is markedly higher, since adults were also examined. The most frequently reported clinical symptom is premature pubarche, with the details on frequency ranging from 45.3 [19] to $88.3 \%$ [18]. If the symptom is considered in relation to sex, the frequency of premature pubarche in girls and boys in our cohort was almost equal, while it was conspicuously more frequent in girls (88.5\%) than in boys (28.9\%) in the Greek cohort [18]. At birth, most of the girls with NC-CAH have unobtrusive external genitalia. However, clitoris hypertrophy may be noticeable when the diagnosis is made. The reported frequencies, ranging from 3.1 [19] to $13.4 \%$ [20] are lower than in our cohort with 19.5\%. The signs of androgenisation increase during puberty and in adulthood $[15,21]$. The numbers on hirsutism vary between 28.6 and $53 \%$ [19, 20]. We are not able to evaluate the linear growth of the children since no old growth data were available at the time of diagnosis. Bone age should also be determined in children with androgenisation. In our cohort, bone age was determined in 97 patients, and in $70(72.2 \%)$ patients, it was $>1$ year accelerated. Symptomatic children can have increased linear growth and accelerated bone age [22]; the final height may, however, be reduced [23]. Children without clinical symptoms have normal linear growth [24]. In our cohort, $12.4 \%$ and in the Greek cohort, $14.6 \%$ of patients were asymptomatic [18].

The mild mutation p.Val281Leu in Exon 7 is found most frequently on the alleles, with frequencies lying between 25 and $50 \%[16,18,19,25]$. In our cohort, this mutation was found most frequently (39\%), followed by mutations p.Pro453S (Exon 10) and Pro30L (Exon 1). The most frequent severe mutation in our cohort was the deletion of the CYP21A2-gene (11.1\%), whereas the Intron 2-mutation IVS2-13A/C $>\mathrm{G}$ was seen most frequently in the Greek cohort [18]. Most of the patients are compound heterozygous for two different mutations of the CYP21A2-gene on both alleles. In our cohort, $68.5 \%$ the patients were compound heterozygous for a severe (classic) and a mild (non-classic) mutation, whereas the percentage (severe/mild) range from $50.4 \%$ in the Greek cohort [18] to $12.6 \%$ in the Turkish cohort [19]. The number of our patients with mild mutations (16.6\%) was lower than in the Turkish cohort $(34 \%)$ and the portion of heterozygous patients in our study (13.4\%) was also markedly lower than in the Turkish population, which was $47.8 \%$ [19]. The diagnosis was made by molecular genetic analysis in seven children during examination of family members with affected siblings at the request of the parents.

The basal 17-OHP concentration in NC-CAH patients is usually raised [14]. Higher 17OHP levels were found in the literature in adolescent girls than in children [20], although we were unable to determine any age differences. Significantly, higher basal 17-OHP levels were found in patients with a compound heterozygous mutation (severe/mild) than in patients with two mild mutations $[18,21,25,26]$. In our cohort, the patients in group 1 (compound heterozygous mutation: severe/ mild) also had higher basal values, and in the ACTH test, they also had higher stimulated 17OHP-values than the patients with two mild mutations (group 2), but the difference was not statistically significant. Basal 17OHP levels $<2 \mathrm{ng} / \mathrm{ml}$ should rule out NC-CAH [13, 27, 28]. This proposition is not shared by all working groups $[18$, $21,29]$. In our cohort, 4 (3.8\%) out of 101 patients with a molecular-genetically confirmed $\mathrm{NC}-\mathrm{CAH}$ (groups 1 and 2) and 6 (2.2\%) out of 280 patients in the Greek cohort had a basal 17OHP level of $<2 \mathrm{ng} / \mathrm{ml}$ [18].

The ACTH stimulation test is regarded as the gold standard in laboratory diagnostics-also in order to differentiate from other non-classic $\mathrm{CAH}$ forms with $11 \beta$ hydroxylase- or $3 \beta$-hydroxysteroid-dehydrogenase deficiency [2]. In our cohort, the test was performed in only $81(61.9 \%)$ out of 134 patients and in 220 (85.2\%) out of 258 patients in the Turkish study. 17OHP levels from > $10 \mathrm{ng} / \mathrm{ml}$ after ACTH stimulation are considered a diagnosis for NC-CAH [13, 21, 30, 31]. However, in an assessment of women with clinical hyperandrogenism, only $24 \%$ of them with a stimulated $17 \mathrm{OHP}>10 \mathrm{ng} / \mathrm{ml}$ had a molecular-genetically confirmed NC-CAH [32]. In our cohort, all patients with NC-CAH had ACTHstimulated $17 \mathrm{OHP}$ values $>10 \mathrm{ng} / \mathrm{ml}$, whereas in the Turkish cohort the percentage was 91.8\% [19]. Heterozygous gene carriers can also be identified with the ACTH 
test, although here there is a greater overlap with the healthy population [31, 33]. Stimulated 17-OHP levels between 2 and $10 \mathrm{ng} / \mathrm{ml}$ have been reported in heterozygous gene carriers [34]. Our results show that a cut-off level of $17 \mathrm{OHP}>10 \mathrm{ng} / \mathrm{ml}$ in the ACTH test does not definitely distinguish heterozygous gene carriers from patients. Of the molecular-genetically confirmed heterozygous individuals in our cohort (group C3), five had an ACTH-stimulated $17 \mathrm{OHP}$ level $>10 \mathrm{ng} / \mathrm{ml}$ and $8 \mathrm{pa}-$ tients had levels $<10 \mathrm{ng} / \mathrm{ml}$.

Since most patients have normal cortisol levels (basal and $60 \mathrm{~min}$ after $\mathrm{ACTH}$ ) and thus react adequately to stress [35-37], measuring cortisol in the $\mathrm{ACTH}$ test is not considered necessary and is not critically examined. In our cohort, a standard ACTH test was performed in 83 patients and cortisol was measured in 73 patients. ACTH-stimulated cortisol values $<180 \mathrm{ng} / \mathrm{ml}(<500 \mathrm{nmol} / \mathrm{l})$ are generally considered to be pathological and are regarded as diminished cortisol reserves. A French working group was able to show that $60 \%$ of children with NC-CAH had diminished cortisol reserves [38]. In our cohort, the proportion was $27.4 \%$, and in other studies, it is between 15.4 and $21.5 \%$ [19, 39]. To date, no generally accepted guidelines for therapy in stress situations have been developed for patients with NC-CAH [40]. Patients with diminished cortisol reserves can only be detected with an ACTH test and receive adequate therapy in stress situations [38].

No significant phenotypical differences were found in a comparison of the three mutation groups. It is remarkable that heterozygous individuals have the same clinical symptoms as the patients in groups $\mathrm{C} 1$ and $\mathrm{C} 2$. It is a known fact that heterozygous gene carriers have symptoms of hyperandrogenism [41]. Women with hyperandrogenism are more frequently identified as heterozygous gene carriers for a non-classic CYP21A2 mutation than in the general population $[42,43]$, but to date, there is no precise explanation for the symptoms described in the heterozygous patients [44].

\section{Conclusion}

The clinical symptoms in patients with non-classic $\mathrm{CAH}$ are variable and sometimes only very mild. The symptoms in the molecular-genetically heterozygous patients are no different from those in the patients with compound heterozygous (severe/mild) or homozygous (mild/mild) mutations. We speculate that many patients, in particular males, have not yet been diagnosed. This is evidenced by the fact that the number of patients who are being treated in the centres involved is lower by a factor of about 5 than the number of patients with classic $\mathrm{CAH}$ with 21hydroxylase defect. The clinical and laboratory diagnostics performed when $\mathrm{NC}-\mathrm{CAH}$ is suspected vary in the different centres. The variability in the laboratory findings demonstrates that a definitive diagnosis can only be confirmed molecular-genetically. It is therefore imperative that a consensus is reached among paediatric endocrinologists in relation to diagnosis of children with NC-CAH.

\section{Abbreviations}

CYP21A2: Cytochrome P450 Family 21 Subfamily A Member 2;

CAH: Congenital adrenal hyperplasia; NC-CAH: Nonclassical congenital

adrenal hyperplasia; MLPA: Multiplex ligation-dependent probe amplification; BMI: Body mass index; SDS: Standard deviation score; 17-OHP: 17-

Hydroxyprogesterone; CA: chronological age; BA: bone age;

ACTH: Adrenocorticotropic hormone; ANOVA: Analysis of variance

\section{Acknowledgements}

We thank Dr. Egbert Schulze for his advice on the molecular genetic diagnostic findings. We thank Mrs. Joanna Voerste for linguistic editing. We also thank the medical staff of the participating hospitals who helped gather data on site.

\section{Authors' contributions}

HGD designed the study. Data collection was performed by NSch. All authors provided patient's records and were involved in data interpretation. The final manuscript was prepared by HGD. All authors read and approved the manuscript for publication.

\section{Funding}

Not applicable.

Availability of data and materials

Not applicable.

\section{Ethics approval and consent to participate}

The study was reviewed and approved by the Ethics Committee of the Medical Faculty of the Friedrich-Alexander-University Erlangen-Nuremberg.

\section{Consent for publication}

Not applicable.

\section{Competing interests}

The authors declare that they have no competing interests. Some of the data was used in a doctoral thesis (N.Sch.).

\section{Author details}

${ }^{1}$ Paediatric Endocrinology, University Children's Hospital, Erlangen, Germany. 2Paediatric Endocrinology, University Children's Hospital, Heidelberg, Germany. ${ }^{3}$ Paediatric Endocrinology, University Children's Hospital, Tübingen, Germany. ${ }^{4}$ Departement of Paediatrics, Hospital Wels-Grieskirchen, Wels, Austria. ${ }^{5}$ Paediatric Endocrinology, University Children's Hospital, Ulm, Germany. ${ }^{6}$ University Children's Hospital I, Augsburg, Germany. ${ }^{7}$ Medical Office, Endokrinologikum, Ulm, Germany. ${ }^{8}$ Paediatric Endocrinology, University Children's Hospital, Munich, Germany. ${ }^{9}$ Paediatric Endocrinology, University Children's Hospital, Freiburg, Germany. ${ }^{10}$ Departament of Paediatrics, Cnopfsche Kinderklinik, Nuremberg, Germany.

Received: 28 June 2020 Accepted: 2 July 2020

Published online: 09 July 2020

\section{References}

1. Hannah-Shmouni F, Morissette R, Sinaii N et al (2017) Revisiting the prevalence of nonclassic congenital adrenal hyperplasia in US Ashkenazi Jews and Caucasians. Genet Med 19:1267-1279

2. White PC, Speiser PW (2000) Congenital adrenal hyperplasia due to 21hydroxylase deficiency. Endocr Rev 21:245-291

3. Krone N, Braun A, Roscher AA et al (2000) Predicting phenotype in steroid 21-hydroxylase deficiency? Comprehensive genotyping in 155 unrelated, 
well defined patients from southern Germany. J Clin Endocrinol Metab 85: 1059-1065

4. Speiser PW, Dupont J, Zhu D et al (1992) Disease expression and molecular genotype in congenital adrenal hyperplasia due to 21-hydroxylase deficiency. J Clin Invest 90:584-595

5. Wedell A, Thilen A, Ritzen EM et al (1994) Mutational spectrum of the steroid 21-hydroxylase gene in Sweden: implications for genetic diagnosis and association with disease manifestation. J Clin Endocrinol Metab 78: 1145-1152

6. Bachega TA, Billerbeck AE, Marcondes JA et al (2000) Influence of different genotypes on 17-hydroxyprogesterone levels in patients with nonclassical congenital adrenal hyperplasia due to 21-hydroxylase deficiency. Clin Endocrinol 52:601-607

7. Tusie-Luna MT, Traktman P, White PC (1990) Determination of functional effects of mutations in the steroid 21-hydroxylase gene (CYP21) using recombinant vaccinia virus. J Biol Chem 265:20916-20922

8. Riedl S, Rohl FW, Bonfig W et al (2019) Genotype/phenotype correlations in 538 congenital adrenal hyperplasia patients from Germany and Austria: discordances in milder genotypes and in screened versus prescreening patients. Endocrine connections 8:86-94

9. Kromeyer-Hauschild K, Wabitsch M, Kunze D, Geller F, Geiß HC, Hesse V, Von Hippel U, Jaeger D, Johnsen W, Korte K, Menner G, Müller J, Müller M, Niemann-Pilatus A, Remer T, Schaefer F, Wittchen HU, Zabransky S, Zellner K, Ziegler A, Hebebrand J (2001) Perzentile für den Body-mass-Index für das Kindes- und Jugendalter unter Heranziehung verschiedener deutscher Stichproben. Monatsschr Kinderheilkd 149:11

10. Greulich WW, Pyle SI (1959) Radiographic atlas of skeletal development of the hand and wrist. Stanford University Press, Stanford

11. Merke DP, Bornstein SR (2005) Congenital adrenal hyperplasia. Lancet 365: 2125-2136

12. New Ml (2004) An update of congenital adrenal hyperplasia. Ann N Y Acad Sci 1038:14-43

13. Speiser PW, Arlt W, Auchus RJ et al (2018) Congenital adrenal hyperplasia due to steroid 21-hydroxylase deficiency: an Endocrine Society Clinical Practice Guideline. J Clin Endocrinol Metab 103:1-46

14. Falhammar $\mathrm{H}$, Nordenstrom A (2015) Nonclassic congenital adrenal hyperplasia due to 21-hydroxylase deficiency: clinical presentation, diagnosis, treatment, and outcome. Endocrine 50:32-50

15. Witchel SF (2012) Nonclassic congenital adrenal hyperplasia. Curr Opin Endocrinol Diabetes Obes 19:151-158

16. New MI (2006) Extensive clinical experience: nonclassical 21-hydroxylase deficiency. J Clin Endocrinol Metab 91:4205-4214

17. Bizzarri C, Crea F, Marini R et al (2012) Clinical features suggestive of nonclassical 21-hydroxylase deficiency in children presenting with precocious pubarche. J Pediatr Endocrinol Metab 25:1059-1064

18. Livadas S, Dracopoulou M, Dastamani A et al (2015) The spectrum of clinical, hormonal and molecular findings in 280 individuals with nonclassical congenital adrenal hyperplasia caused by mutations of the CYP21A2 gene. Clin Endocrinol 82:543-549

19. Savas-Erdeve S, Cetinkaya S, Abali ZY et al (2017) Clinical, biochemical and genetic features with nonclassical 21-hydroxylase deficiency and final height. J Pediatr Endocrinol Metab 30:759-766

20. Moran C, Azziz R, Carmina E et al (2000) 21-Hydroxylase-deficient nonclassic adrenal hyperplasia is a progressive disorder: a multicenter study. Am J Obstet Gynecol 183:1468-1474

21. Bidet M, Bellanne-Chantelot C, Galand-Portier MB et al (2009) Clinical and molecular characterization of a cohort of 161 unrelated women with nonclassical congenital adrenal hyperplasia due to 21-hydroxylase deficiency and 330 family members. J Clin Endocrinol Metab 94:1570-1578

22. Einaudi S, Napolitano E, Restivo F et al (2011) Genotype, phenotype and hormonal levels correlation in non-classical congenital adrenal hyperplasia. $J$ Endocrinol Investig 34:660-664

23. Eyal O, Tenenbaum-Rakover Y, Shalitin S et al (2013) Adult height of subjects with nonclassical 21-hydroxylase deficiency. Acta Paediatr 102:419-423

24. Pijnenburg-Kleizen KJ, Borm GF, Otten BJ et al (2012) Absence of clinically relevant growth acceleration in untreated children with non-classical congenital adrenal hyperplasia. Horm Res Paediatr 77:164-169

25. Ezquieta B, Cueva E, Varela J et al (2002) Non-classical 21-hydroxylase deficiency in children: association of adrenocorticotropic hormonestimulated 17-hydroxyprogesterone with the risk of compound heterozygosity with severe mutations. Acta Paediatr 91:892-898
26. Skordis N, Shammas C, Efstathiou E et al (2011) Endocrine profile and phenotype-genotype correlation in unrelated patients with non-classical congenital adrenal hyperplasia. Clin Biochem 44:959-963

27. Armengaud JB, Charkaluk ML, Trivin C et al (2009) Precocious pubarche: distinguishing late-onset congenital adrenal hyperplasia from premature adrenarche. J Clin Endocrinol Metab 94:2835-2840

28. Azziz R, Zacur HA (1989) 21-Hydroxylase deficiency in female hyperandrogenism: screening and diagnosis. J Clin Endocrinol Metab 69: $577-584$

29. Bello R, Lebenthal $Y$, Lazar $L$ et al (2017) Basal 17-hydroxyprogesterone cannot accurately predict nonclassical congenital adrenal hyperplasia in children and adolescents. Acta Paediatr 106:155-160

30. Dewailly D, Vantyghem-Haudiquet MC, Sainsard C et al (1986) Clinical and biological phenotypes in late-onset 21-hydroxylase deficiency. J Clin Endocrinol Metab 63:418-423

31. New Ml, Lorenzen F, Lerner AJ et al (1983) Genotyping steroid 21hydroxylase deficiency: hormonal reference data. J Clin Endocrinol Metab 57:320-326

32. Ambroziak U, Kepczynska-Nyk A, Kurylowicz A et al (2016) The diagnosis of nonclassic congenital adrenal hyperplasia due to 21-hydroxylase deficiency, based on serum basal or post-ACTH stimulation 17-hydroxyprogesterone, can lead to false-positive diagnosis. Clin Endocrinol 84:23-29

33. Witchel SF, Lee PA (1998) Identification of heterozygotic carriers of 21hydroxylase deficiency: sensitivity of ACTH stimulation tests. Am J Med Genet 76:337-342

34. Wilson RC, Mercado AB, Cheng KC et al (1995) Steroid 21-hydroxylase deficiency: genotype may not predict phenotype. J Clin Endocrinol Metab 80:2322-2329

35. Feuillan P, Pang S, Schurmeyer T et al (1988) The hypothalamic-pituitaryadrenal axis in partial (late-onset) 21-hydroxylase deficiency. J Clin Endocrinol Metab 67:154-160

36. Huerta R, Dewailly D, Decanter C et al (2000) Adrenocortical hyperresponsivity to adrenocorticotropic hormone: a mechanism favoring the normal production of cortisol in 21-hydroxylase-deficient nonclassic adrenal hyperplasia. Fertil Steril 74:329-334

37. Trakakis E, Chryssikopoulos A, Sarandakou A et al (2001) Hypothalamicpituitary-thyroidal axis dysfunction and cortisol secretion in patients with nonclassical congenital adrenal hyperplasia. Int J Fertil Womens Med 46:37-41

38. Stoupa A, Gonzalez-Briceno L, Pinto G et al (2015) Inadequate cortisol response to the tetracosactide (Synacthen(R)) test in non-classic congenital adrenal hyperplasia: an exception to the rule? Horm Res Paediatr 83:262-267

39. Karachaliou FH, Kafetzi M, Dracopoulou M et al (2016) Cortisol response to adrenocorticotropin testing in non-classical congenital adrenal hyperplasia (NCCAH). J Pediatr Endocrinol Metab 29:1365-1371

40. Mccann-Crosby B, Chen MJ, Lyons SK et al (2014) Nonclassical congenital adrenal hyperplasia: targets of treatment and transition. Pediatr Endocrinol Rev 12:224-238

41. Lajic S, Clauin S, Robins T et al (2002) Novel mutations in CYP21 detected in individuals with hyperandrogenism. J Clin Endocrinol Metab 87:2824-2829

42. Blanche H, Vexiau P, Clauin S et al (1997) Exhaustive screening of the 21hydroxylase gene in a population of hyperandrogenic women. Hum Genet 101:56-60

43. Witchel SF, Lee PA, Suda-Hartman M et al (1997) Hyperandrogenism and manifesting heterozygotes for 21-hydroxylase deficiency. Biochem Mol Med 62:151-158

44. Pignatelli D, Carvalho BL, Palmeiro A et al (2019) The complexities in genotyping of congenital adrenal hyperplasia: 21-hydroxylase deficiency. Front Endocrinol 10:432

\section{Publisher's Note}

Springer Nature remains neutral with regard to jurisdictional claims in published maps and institutional affiliations. 